\title{
Effect of a phospho-oligosaccharidic putative insulin messenger on insulin release in rats
}

\author{
W.J. Malaisse ${ }^{1}$, A. Albor ${ }^{2}$, F. Blachier ${ }^{1}$, I. Valverde ${ }^{2}$, A. Sener ${ }^{1}$ and J.M. Mato ${ }^{2}$ \\ ${ }^{1}$ Laboratory of Experimental Medicine, Brussels Free University, Belgium and \\ ${ }^{2}$ Fundacion Jimenez Diaz, Centro Associado al Consejo Superior de Investigaciones Cientificas, Madrid, Spain
}

Summary. The phospho-oligosaccharide extracted from rat liver and supposed to act as the insulin second messenger inhibits glucose-stimulated insulin release. In the present study, this phospho-oligosaccharide was found not to affect D-[U${ }^{14} \mathrm{Clglucose}$ oxidation and ${ }^{45} \mathrm{Ca}$ net uptake, but to inhibit insulin release evoked by either D-glucose or 2-ketoisocaproate in isolated rat islets. The relative extent of the latter inhibition was unaffected by either the concentration of D-glucose or the presence of dibutyryl-cyclic AMP, forskolin or glucagon in the incubation medium. At variance with the inhibitory effect of clonidine, that of the phospho-oligosaccharide was resistant to both blockade of $\alpha_{2}$-adrenergic receptors or pre-treatment with the toxin of Bordetella pertussis. It is speculated, therefore, that such a phospho-oligosaccharide might interfere with a distal event in the insulin secretory sequence.

Key words: Insulin release, pancreatic islets, phospho-oligosaccharide, insulin messenger.
In several target cells, insulin provokes, by a phospholipase $\mathrm{C}$ mechanism, the generation from a glycolipid of a phospho-oligosaccharide (POS), which is thought to act as the insulin "second messenger" [1-4]. It was recently reported that pancreatic islet cells contain a comparable glycolipid and that POS, extracted from rat liver, inhibits insulin secretion [5]. The present study deals with the possible mode of action of POS upon insulin release from isolated rat islets.

\section{Materials and methods}

POS was prepared from rat liver by a method described elsewhere [6]. Briefly, a liver membrane fraction was extracted with acidified chloroform/methanol and the insulin-sensitive glycophospholipid first isolated by successive thin layer chromatographies on silica gel $\mathrm{G}$ and then treated with the phospholipase $\mathrm{C}$ of $S$. aureus. The $\mathrm{H}_{2} \mathrm{O}$-soluble POS generated in this manner amounts to about 20 (range 8 to 40 ) nmol per rat liver. One unit of POS is here arbitrarily defined as the material extracted from the liver of one rat. Highly purified porcine glucagon and idazoxan were kindly provided by Novo Research Institute (Bagsvaerd, Denmark) and Reckitt and Colman (Kingstonupon-Hull, U.K.), respectively.

All experiments were conducted in isolated islets removed from fed albino rats [7]. In one series of experiments, six rats (182 $\pm 4 \mathrm{~g}$ body weight) were injected intraperitoneally with the toxin of Bordetella pertussis (2.8 $\mu \mathrm{g}$ per rat; [8]) and killed 48 to $72 \mathrm{~h}$ later. In these animals, the daily gain in body weight did not exceed $0.7 \pm 1.2 \mathrm{~g}(n=6)$.
The oxidation of $\mathrm{D}-\left[\mathrm{U}-{ }^{14} \mathrm{C}\right]$-glucose [9], net uptake of ${ }^{45} \mathrm{Ca}[10]$ and release of insulin [7] by the islets were all measured over 90 min incubation by methods described in the cited references. Neither POS, nor glucagon interfered with the immunoassay of insulin.

In control experiments, no inhibition of glucose-stimulated insulin release was observed when fractions, other than those containing the insulin-sensitive glycophospholipid, were derived from the second chromatography of the liver extract and treated with the phosphatidylinositol-specific phospholipase $\mathrm{C}$ from Bacillus cereus [6]. Likewise, glucose-stimulated insulin release was not significantly affected by either material obtained when the liver lipid fraction had not been exposed to the specific phospholipase $\mathrm{C}$ or blank material prepared

Table 1. Effect of a phospho-oligosaccharide (POS), prepared by exposure of an insulin-sensitive glycophospholipid to a specific phospholipase C (PLC), upon glucose-stimulated insulin release

\begin{tabular}{llr}
\hline $\begin{array}{l}\text { D-glucose } \\
(\mathrm{mmol} / \mathrm{l})\end{array}$ & $\begin{array}{l}\text { Tested material } \\
(0.2 \mathrm{U} / \mathrm{ml})\end{array}$ & $\begin{array}{c}\text { Insulin output } \\
(\text { normalized })^{\mathbf{a}}\end{array}$ \\
\hline $\mathrm{Nil}$ & & $6.7 \pm 2.2(9)$ \\
16.7 & & $100.0 \pm 3.8(27)$ \\
16.7 & POS & $67.0 \pm 5.3(27)$ \\
16.7 & No PLC & $93.2 \pm 6.8(18)$ \\
16.7 & Blank & $99.7 \pm 5.6(9)$ \\
16.7 & Inactivated POS & $101.4 \pm 9.9(9)$ \\
\hline
\end{tabular}

${ }^{\text {a }}$ All secretory data are expressed as $\%$ of the mean value found within the same experiment(s) in the sole presence of D-glucose $(16.7 \mathrm{mmol} / \mathrm{l})$. Such a control output averaged $318.9 \pm 21.9$ $\mu \mathrm{U} / 90 \mathrm{~min}$ per islet 

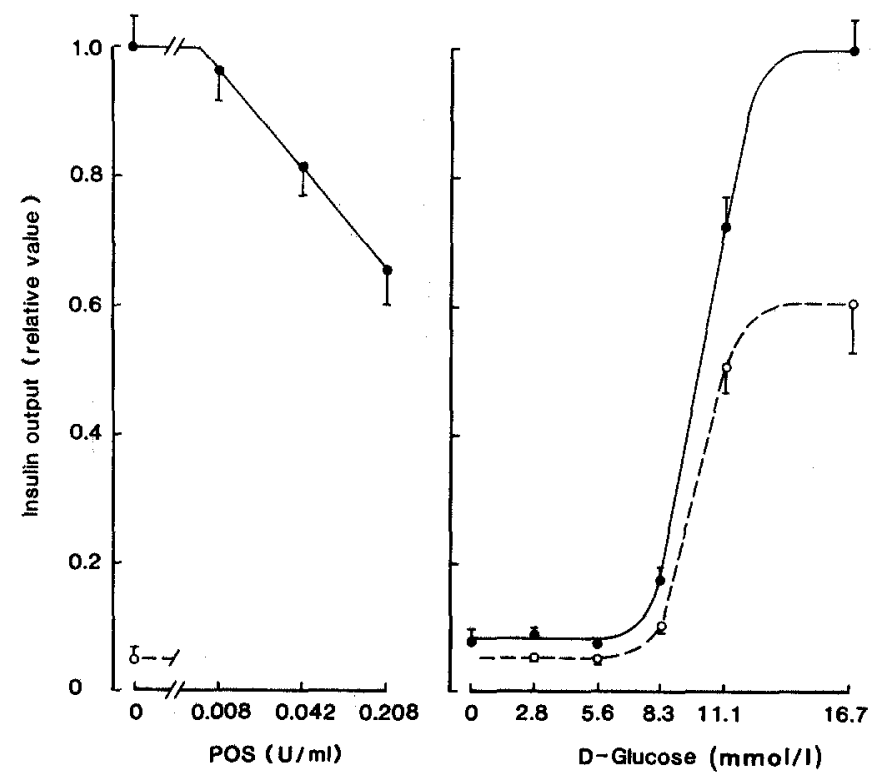

Fig. 1. Left panel: effect of increasing concentrations of a phosphooligosaccharide (POS; logarithmic scale) upon insulin release evoked by D-glucose $(16.7 \mathrm{mmol} / \mathrm{l})$ the basal insulin output (no glucose) being shown as an open circle. Right panel: effect of increasing concentrations of D-glucose (cartesian scale) upon insulin output in the absence (closed circles and solid line) or presence (open circles and dashed line) of POS $(0.2 \mathrm{U} / \mathrm{ml})$. Mean values $\pm S E M$ for insulin output ( $\mu \mathrm{U} / 90 \mathrm{~min}$ per islet) refer to $19-20$ (left panel) and 8-25 (right panel) individual measurements and are expressed relative to the mean control secretory rate found in the sole presence of $16.7 \mathrm{mmol} / 1$ D-glucose

in the absence of liver lipid but the presence of the specific phospholipase C (Table 1). The inhibitory action of POS upon insulin release was suppressed after its inactivation by nitrous acid, followed by chromatography on a Dowex AG-1-X8 column [6].

\section{Statistical analysis}

All results are presented as the mean \pm SEM together with the number of individual observations $(n)$. The statistical significance of differences between mean values was assessed by the use of Student's $t$-test.

\section{Results}

\section{Effect of POS upon D-glucose oxidation}

Whether at low $(2.8 \mathrm{mmol} / \mathrm{l})$ or high $(16.7 \mathrm{mmol} / \mathrm{l})$ concentration of D-glucose, POS $(0.04$ to $0.21 \mathrm{U} / \mathrm{ml})$ failed to affect significantly $(p>0.1)$ the oxidation of $\mathrm{D}$ $\left[\mathrm{U}-{ }^{14} \mathrm{C}\right] \mathrm{glucose}$ by isolated rat islets (Table 2).

\section{Effect of POS upon ${ }^{45}$ Ca net uptake}

A rise in D-glucose concentration from 2.8 to $16.7 \mathrm{mmol} / 1$ provoked a two- to three-fold increase in ${ }^{45} \mathrm{Ca}$ net uptake by the islets $(p<0.001)$. At both hexose concentrations, POS $(0.04$ to $0.21 \mathrm{U} / \mathrm{ml})$ failed to affect significantly $(p>0.6)$ the net uptake of ${ }^{45} \mathrm{Ca}$ (Table 3).

\section{Effect of POS upon nutrient-stimulated insulin release}

In the absence of POS, D-glucose, in concentrations above $5.6 \mathrm{mmol} / 1$, stimulated insulin release, with a sigmoidal concentration-response relationship (Fig.1, right panel). In the presence of $\mathrm{D}$-glucose $(16.7 \mathrm{mmol} / \mathrm{l})$, POS $(0.04$ to $0.21 \mathrm{U} / \mathrm{ml})$ caused a concentration-related inhibition of insulin release (Fig.1, left panel). The relative extent of the inhibitory action of POS was little affected by either the length of incubation (60 to $90 \mathrm{~min}$; data not shown) or, as documented in Table 4, by the concentration of D-glucose used to stimulate insulin release. The close-to-basal insulin output recorded at low concentrations of the hexose $(2.8$ or $5.6 \mathrm{mmol} / 1)$ was also decreased by POS $(p<0.05)$. POS inhibited insulin release evoked, in the absence of $\mathrm{D}$-glucose, by 2-ketoisocaproate $(10 \mathrm{mmol} / \mathrm{l})$. It should be underlined that, at the concentrations of POS used in most of the present experiments $(0.13$ to $0.21 \mathrm{U} / \mathrm{ml})$, the relative extent of the inhibitory action of POS upon insulin release did not exceed 30 to $40 \%$ of the control value (Table 4 ).

\section{Effect of POS upon insulin release attributable to cyclic AMP}

Since POS may mediate, in selected target cells, the inhibitory action of insulin upon agonist-stimulated adenylate cyclase activity, we have examined the effect of POS upon insulin release evoked by secretagogues affecting cyclic AMP generation in the islets (Table 5). These experiments were all performed in the presence of $16.7 \mathrm{mmol} / 1 \mathrm{D}$-glucose, because all the agents tested (db-cAMP, forskolin and glucagon) fail to affect insulin release in the absence of exogenous nutrient, but markedly augment glucose-stimulated insulin output $[11,12]$. Exogenous db-cAMP indeed significantly augmented glucose-stimulated insulin release, both in the absence

Table 2. Effect of a phospho-oligosaccharide (POS) upon D-[U${ }^{14} \mathrm{Clglucose}$ oxidation

\begin{tabular}{|c|c|c|c|}
\hline \multirow{2}{*}{$\begin{array}{l}\text { D-glucose } \\
(\mathrm{mmol} / \mathrm{l})\end{array}$} & \multicolumn{3}{|l|}{ POS } \\
\hline & Nil & $0.04 \mathrm{U} / \mathrm{ml}$ & $0.21 \mathrm{U} / \mathrm{ml}$ \\
\hline 2.8 & $5.62 \pm 0.05(8)^{\mathrm{a}}$ & $5.67 \pm 0.80(8)$ & $6.00 \pm 0.38(8)$ \\
\hline 16.7 & $28.61 \pm 1.89(8)$ & $24.90 \pm 1.59(8)$ & $25.33 \pm 1.08(8)$ \\
\hline
\end{tabular}

${ }^{a}$ Mean values $\pm S E M$ are expressed as pmol/islet per $90 \mathrm{~min}$

Table 3. Effect of a phospho-oligosaccharide (POS) upon ${ }^{45} \mathrm{Ca}$ net uptake

\begin{tabular}{|c|c|c|c|}
\hline \multirow{2}{*}{$\begin{array}{l}\text { D-glucose } \\
(\mathrm{mmol} / \mathrm{l})\end{array}$} & POS & \multicolumn{2}{|l|}{$\therefore$} \\
\hline & Nil & $0.04 \mathrm{U} / \mathrm{ml}$ & $0.21 \mathrm{U} / \mathrm{ml}$ \\
\hline 2.8 & $1.20 \pm 0.16(10)^{\mathrm{a}}$ & $1.15 \pm 0.16(10)$ & $1.24 \pm 0.11(10)$ \\
\hline 16.7 & $2.87 \pm 0.24$ & $2.80 \pm 0.17$ & $3.02 \pm 0.29(10)$ \\
\hline
\end{tabular}

a Mean values \pm SEM are expressed as pmol/islet at the 90 th $\min$ of incubation 
Table 4. Effect of a phospho-oligosaccharide (POS) upon nutrient-stimulated insulin release

\begin{tabular}{|c|c|c|c|c|c|}
\hline \multirow{2}{*}{$\begin{array}{l}\text { Nutrient } \\
\text { (mmol/1) }\end{array}$} & \multicolumn{2}{|c|}{ Insulin output ( $\mu \mathrm{U} / 90 \mathrm{~min}$ per islet) } & \multirow{2}{*}{$\begin{array}{l}\mathrm{POS} \\
(\mathrm{U} / \mathrm{ml})\end{array}$} & \multicolumn{2}{|c|}{ POS/Control } \\
\hline & Control & POS & & $(\%)$ & $p$ \\
\hline Nil & $26.8 \pm 6.2(25)$ & N.D. ${ }^{\mathrm{a}}$ & & & \\
\hline D-glucose (2.8) & $31.3 \pm 3.0$ & $18.9 \pm 1.9$ & 0.18 & $60.4 \pm 11.3$ & $<0.005$ \\
\hline D-glucose $(5.6)$ & $25.2 \pm 2.4$ & $17.5 \pm 2.5$ & 0.18 & $69.4 \pm 13.7$ & $<0.050$ \\
\hline D-glucose (8.3) & $59.8 \pm 6.3$ & $36.0 \pm 4.3$ & 0.18 & $61.0 \pm 12.8$ & $<0.010$ \\
\hline D-glucose (11.1) & $245.5 \pm 14.9(10)$ & $173.0 \pm 15.0(10)$ & 0.21 & $70.5 \pm 8.6$ & $<0.005$ \\
\hline D-glucose (16.7) & $338.3 \pm 35.7$ & $205.0 \pm 26.6(10)$ & 0.21 & $60.6 \pm 13.2$ & $<0.010$ \\
\hline 2-ketoisocaproate (10.0) & $81.8 \pm 8.8(15)$ & $50.7 \pm 7.7(14)$ & 0.13 & $62.0 \pm 14.3$ & $<0.020$ \\
\hline
\end{tabular}

${ }^{a}$ N.D.: Not determined

Table 5. Effect of a phospho-oligosaccharide (POS) upon insulin release attributable to cyclic AMP

\begin{tabular}{|c|c|c|c|c|c|c|c|c|}
\hline \multirow{2}{*}{$\begin{array}{l}\text { Experiment } \\
\text { Number }\end{array}$} & \multirow{2}{*}{$\begin{array}{l}\text { Db-cAMP } \\
(\mathrm{mmol} / \mathrm{l})\end{array}$} & \multirow{2}{*}{$\begin{array}{l}\text { Forskolin } \\
(\text { Hol/1) }\end{array}$} & \multirow{2}{*}{$\begin{array}{l}\text { Glucagon } \\
(\mu \mathrm{mol} / 1)\end{array}$} & \multicolumn{2}{|c|}{ Insulin output (normalized) } & \multirow{2}{*}{$\begin{array}{l}\text { POS } \\
\mathrm{U} / \mathrm{ml}\end{array}$} & \multicolumn{2}{|c|}{ POS/Control } \\
\hline & & & & Control & POS & & $(\%)$ & $p$ \\
\hline 1 & $\overline{0.5}$ & $\begin{array}{l}- \\
-\end{array}$ & - & $\begin{array}{l}100.0 \pm 8.7(10) \\
152.2 \pm 13.0(10)\end{array}$ & $\begin{array}{l}66.3 \pm 9.2(10) \\
97.3 \pm 12.5(10)\end{array}$ & $\begin{array}{l}0.18 \\
0.18\end{array}$ & $\begin{array}{l}66.3 \pm 12.7 \\
63.9 \pm 11.8\end{array}$ & $\begin{array}{l}<0.02 \\
<0.01\end{array}$ \\
\hline 2 & $\begin{array}{l}- \\
-\end{array}$ & $\overline{5} .0$ & - & $\begin{array}{l}100.0 \pm 13.9(12) \\
219.0 \pm 14.2(12)\end{array}$ & $\begin{array}{r}60.9 \pm 8.9(12) \\
152.3 \pm 17.6(11)\end{array}$ & $\begin{array}{l}0.13 \\
0.13\end{array}$ & $\begin{array}{l}60.9 \pm 16.5 \\
69.5 \pm 14.8\end{array}$ & $\begin{array}{l}<0.05 \\
<0.01\end{array}$ \\
\hline 3 & $\begin{array}{l}- \\
-\end{array}$ & $\begin{array}{l}- \\
-\end{array}$ & $\overline{0} .2$ & $\begin{array}{l}100.0 \pm 7.9(12) \\
156.6 \pm 10.8(12)\end{array}$ & $\begin{array}{r}69.4 \pm 6.5(12) \\
113.4 \pm 12.6(12)\end{array}$ & $\begin{array}{l}0.17 \\
0.17\end{array}$ & $\begin{array}{l}69.4 \pm 10.2 \\
72.4 \pm 10.6\end{array}$ & $\begin{array}{l}<0.01 \\
<0.02\end{array}$ \\
\hline
\end{tabular}

${ }^{a}$ All secretory rates were measured in the presence of D-glucose $(16.7 \mathrm{mmol} / \mathrm{l})$ and are expressed as $\%$ of the mean value found within the same experiments in the sole presence of the hexose

Table 6. Comparison between the effects of a phospho-oligosaccharide (POS) and clonidine upon insulin release

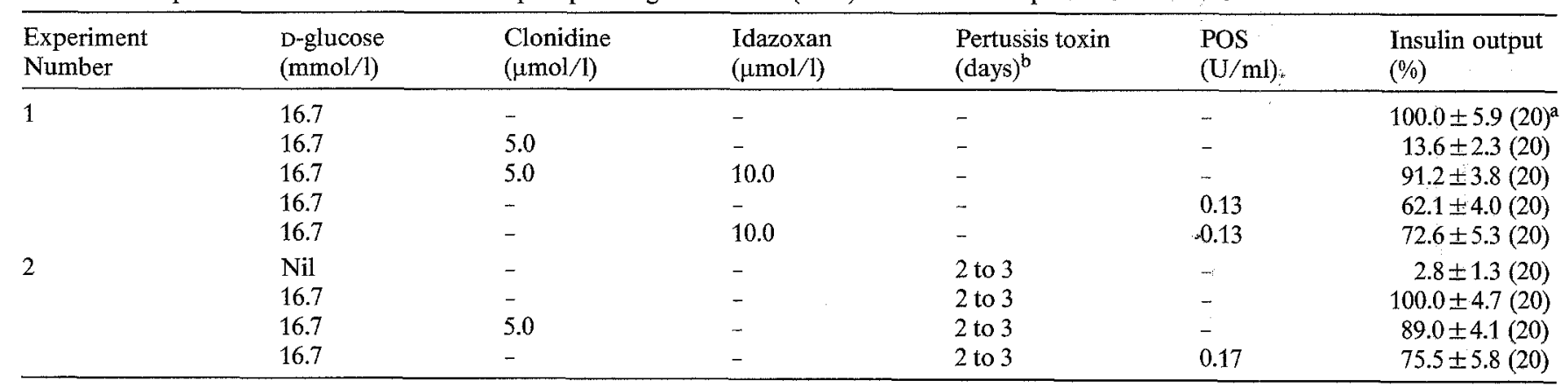

${ }^{a}$ All secretory rates are expressed as \% of the mean control value found, within the same experiments, in the sole presence of $\mathrm{D}$-glucose $(16.7 \mathrm{mmol} / 1) ;{ }^{b}$ Number of days between the injection of pertussis toxin and isolation of the islets

and presence of POS $(p<0.05)$. POS decreased insulin output to the same relative extent in the absence and presence of db-cAMP. Comparable results were obtained in the case of forskolin and glucagon, which again augmented insulin output both in the absence and presence of POS $(p<0.01)$. The relative extent of the inhibitory action of POS upon insulin release was not significantly different in the presence and absence, respectively, of either forskolin or glucagon.

\section{Comparison between the secretory responses to POS and clonidine}

The inhibitory action of POS upon insulin release differed from that of clonidine by its resistance to the an- tagonistic effect of the $\alpha_{2}$-adrenergic blocking agent idazoxan (Table 6). Indeed, whereas clonidine exerted a much more severe inhibition of insulin release than POS $(p<0.001)$, the adrenergic agent failed to affect significantly insulin release in the presence of idazoxan $(p>0.2)$. In the presence of POS, however, idazoxan failed to affect significantly insulin output $(p>0.1)$. As a consequence of these contrasting effects, the release of insulin was lower in the presence of POS than clonidine $(p<0.01)$ when the islets were exposed to both D-glucose and idazoxan.

Comparable results were obtained when the islets were removed from rats injected with the toxin of Bordetella pertussis and killed 2 to 3 days later. In such a case, the release of insulin evoked by D-glucose averaged $447.0 \pm 22.5 \mu \mathrm{U} / 90 \mathrm{~min}$ per islet $(n=20)$, which is 
higher $(p<0.005)$ than the mean value recorded, within the same series of experiments, in islets removed from control rats $(339.9 \pm 20.7 \mu \mathrm{U} / 90 \mathrm{~min}$ per islet; $n=20$ ). Clonidine failed to significantly decrease insulin release in the islets removed from the toxin-treated rats $(p>0.05)$. However, in the latter islets, POS still caused inhibition of insulin release $(p<0.005)$. The relative extent of such an inhibition was comparable $(p>0.7)$ to that evoked by POS in islets removed from control rats and exposed to idazoxan and not significantly different $(p>0.05)$ from that evoked by POS in control islets not exposed to idazoxan.

\section{Discussion}

In several tissues exposed to insulin, POS appears to be generated at the outer surface of the cell and released in the extracellular medium and, then, to act upon target cells [13-15]. The exposure of intact cells to POS would seem appropriate, therefore, to investigate the mode of action of this presumed insulin second messenger.

The present results confirm that POS inhibits glucose-stimulated insulin release [5]. In this series of experiments, the relative extent of such an inhibitory action did not exceed 30 to $40 \%$ of the control secretory rate. It is conceivable, however, that higher concentrations of POS may exert a more pronounced inhibition of insulin release [5].

It seems unlikely that POS specifically interferes with the process of glucose identification by the B cell, as presumably linked to the catabolism of the hexose [16]. Indeed, POS failed to affect $\mathrm{D}-\left[\mathrm{U}-{ }^{14} \mathrm{C}\right] \mathrm{glucose}$ oxidation by the islets, and inhibited insulin release evoked by the nutrient secretagogue 2-ketoisocaproate.

A primary action of POS upon those cationic events participating in the process of nutrient-stimulated insulin release cannot be ruled out. The finding that POS failed to affect both basal and glucose-stimulated ${ }^{45} \mathrm{Ca}$ net uptake argues, however, against such a view.

The data collected in islets exposed to db-cAMP, forskolin and glucagon further suggest that POS does not interfere preferentially with either the generation of cyclic AMP or the functional response to this nucleotide. Indeed, the relative extent of the inhibitory action of POS upon glucose-induced insulin release was similar in the absence and presence of db-cAMP, forskolin or glucagon.

The inhibitory action of POS upon insulin release differed vastly from that of clonidine, by its resistance to the antagonistic effect of either a selective $\alpha_{2}$ adrenergic blocking agent (idazoxan) or pre-treatment with the toxin of Bordetella pertussis. These findings argue against the hypothesis that the action of POS is mediated at the intervention of $\alpha_{2}$-adrenergic receptors and/or the GTP-binding protein Ni previously identified in islet cells [8]. Incidentally, we also observed that clonidine fails to affect the efflux of radioactivity from islets pre-incubated with $\mathrm{D}-\left[1-{ }^{14} \mathrm{C}\right]$ galactose or $\mathrm{D}-[1$ ${ }^{14}$ Clglucosamine (unpublished observation) in order to label the insulin-sensitive glycolipid [5]. This suggests that the generation of POS is not stimulated by the occupancy of $\alpha_{2}$-adrenergic receptors.

Taken as a whole, these findings suggest that POS may act upon insulin release at a rather distal site in the secretory sequence, e.g. at the level of those biochemical reactions involved in the activation of the effector system responsible for the translocation of secretory granules and their access to the exocytotic site. For instance, the participation of specific protein-kinases in these motile events could conceivably represent a site of action for POS $[6,17,18]$.

Whatever its intimate mode of action, the finding that POS inhibits insulin release evoked by distinct secretagogues could be relevant to the response of the $B$ cell to either insulin itself or somatomedin-C. It was indeed recently proposed that purified $\mathrm{B}$ cells are devoid of high-affinity insulin receptors but are equipped with IGF-1 receptors through which insulin, in high concentrations, could conceivably affect B cell growth or function [19-20]. We have so far been unable, however, to detect any obvious effect of insulin, anti-insulin serum or somatomedin-C upon insulin release from isolated rat islets [21-23]. Moreover, there is yet no evidence that the occupancy of IGF-1 receptors affects POS production.

In conclusion, POS inhibits insulin release apparently by interfering with a late event in the secretory sequence, at a site distal to those metabolic and cationic events involved in the process of nutrient-stimulated insulin secretion. Further work is obviously required, to progress in our understanding of both the mode of action of POS upon insulin release and the identity of those first messengers which might stimulate its generation in islet cells.

Acknowledgements. This research was supported by grants from the Belgian Foundation for Scientific Medical Research, Belgian Ministry of Scientific Policy, Spanish National Health Institute and Spanish Commission for Scientific Investigation. The authors are grateful to M. Mahy for technical assistance and C. Demesmaeker for secretarial help.

\section{References}

1. Saltiel AR, Fox JA, Sherline P, Cuatrecasas $P$ (1986) Insulinstimulated hydrolysis of a novel glycolipid generates modulators of cAMP phosphodiesterase. Science 233: 967-972

2. Mato JM, Kelly KL, Abler A, Jarett L (1987) Identification of a novel insulin-sensitive glycophospholipid from $\mathrm{H} 35$ hepatoma cells. J Biol Chem 262: 2131-2137

3. Saltiel AR (1987) Insulin generates an enzyme modulator from hepatic plasma membranes: regulation of adenosine $3^{\prime}: 5^{\prime}$-mono- 
phosphate phosphodiesterase, pyruvate dehydrogenase, and adenylate cyclase. Endocrinology 120:967-972

4. Kelly KL, Mato JM, Merida I, Jarett L (1987) Glucose transport and antilipolysis are differentially regulated by the polar head group of an insulin-sensitive glycophospholipid. Proc Natl Acad Sci USA 84: 6404-6407

5. Albor A, Camara J, Valverde I, Mato JM, Malaisse WJ (1988) Inhibition of insulin release by a putative insulin-mediator in pancreatic islet cells. Med Sci Res 17: 161-162

6. Villalba M, Kelly KL, Mato JM (1988) Inhibition of cyclic AMPdependent protein kinase by the polar head group of an insulinsensitive glycophospholipid. Biochim Biophys Acta 968: 69-76

7. Malaisse-Lagae F, Malaisse WJ (1984) Insulin release by pancreatic islets. In: Larner J, Pohl SL (eds) Methods in diabetes research, Vol 1. Wiley, Chichester New York Brisbane, Toronto, pp 147-152

8. Malaisse WJ, Svoboda M, Dufrane SP, Malaisse-Lagae F, Christophe J (1984) Effect of Bordetella Pertussis toxin on ADP-ribosylation of membrane proteins, adenylate cyclase activity and insulin release in rat pancreatic islets. Biochem Biophys Res Commun 124: $190-196$

9. Carpinelli AR, Sener A, Herchuelz A, Malaisse WJ (1980) The stimulus-secretion coupling of glucose-induced insulin release. XLI.Effect of intracellular acidification upon calcium efflux from islet cells. Metabolism 29: 540-545

10. Malaisse-Lagae F, Malaisse WJ (1981) The stimulus-secretion coupling of glucose-induced insulin release. III. Uptake of ${ }^{45} \mathrm{cal}-$ cium by isolated islets of Langerhans. Endocrinology 88: 72-80

11. Malaisse WJ, Malaisse-Lagae F, Mayhew DA (1967) A possible role for the adenylate cyclase system in insulin secretion. J Clin Invest 46: 1724-1734

12. Malaisse WJ, Garcia-Morales P, Dufrane SP, Sener A, Valverde I (1984) Forskolin-induced activation of adenylate cyclase, cyclic adenosine monophosphate production and insulin release in rat pancreatic islets. Endocrinology 115: 2015-2020

13. Alvarez JF, Varela I, Ruiz-Albusac JM, Mato JM (1988) Localisation of the insulin-sensitive phosphatidylinositol glycan at the outer surface of the cell membrane. Biochem Biophys Res Commun 152: 1455-1462

14. Rometo G, Luttrell L, Rogol A, Zeller K, Hewlett E, Larner J
(1988) Phosphatidylinositol-glycan anchors of membrane proteins: potential precursors of insulin mediators. Science 240: $501-511$

15. Saltiel AR, Sorbara-Cazan LR (1987) Inositol glycan mimics the action of insulin on glucose utilization in rat adipocytes. Biochem Biophys Res Commun 149: 1084-1092

16. Malaisse WJ, Sener A, Herchuelz A, Hutton JC (1979) Insulin release: the fuel hypothesis. Metabolism 28: 373-386

17. Kelly KL, Merida I, Wong EHA, DiCenzo D, Mato JM (1987) A phosphooligosaccharide mimics the effect of insulin to inhibit isoproterenol-dependent phosphorylation of phospholipid methyltransferase in isolated hepatocytes. J Biol Chem 262: 15285-15290

18. Alemany S, Mato JM, Strålfors IP (1987) Phospho-dephosphocontrol by insulin is mimicked by a phospho-oligosaccharide in adipocytes. Nature 330: 77-79

19. Van Schravendijk CFH, Foriers A, Van den Brande JL, Pipeleers DG (1987) Evidence for the presence of type I insulin-like growth factor receptors on rat pancreatic $\mathrm{A}$ and $\mathrm{B}$ cells. Endocrinology 121: 1784-1788

20. Van Schravendijk CFH, Pezzino V, Vigneri R, Pipeleers DG (1988) Insulin receptors in pancreatic B- and A-cells. Diabetes 37 [Suppl 1]: 187A (Abstract)

21. Malaisse WJ, Malaisse-Lagae F, Lacy PE, Wright PH (1967) Insulin secretion by isolated islets in the presence of glucose, insulin, and anti-insulin serum. Proc Soc Exp Biol Med 124: 497-500

22. Malaisse WJ (1988) Dual role of lipids in the stimulus-secretion coupling for insulin release. Biochem Soc Trans 17:59-60

23. Malaisse WJ (1988) Effect of somatomedin C upon insulin release. Med Sci Res 16: 939

Received: 15 December 1988

and in revised form: 13 March 1989

Prof. W.J. Malaisse

Laboratory of Experimental Medicine

Brussels Free University

115 Boulevard de Waterloo

B-1000 Brussels

Belgium 